\title{
THERMODYNAMIC ANALYSIS FOR PERFORMANCE IMPROVEMENT OF POWER PLANT BY FLUE GAS HEAT RECOVERY SYSTEM
}

\section{RITESH KUMAR CHAURASIYA, PRIYASH AGARWAL, ANIRUDH CHAWLA \& SHUBHAM SHARMA}

Department of Mechanical Engineering, SRM University, Uttar Pradesh, India

\begin{abstract}
This analysis shows that how the performance of a thermal power plant can be improved by utilization of waste exhaust flue gas energy. In a power plant, most of the heat loss is from the high-temperature flue gas leaving the boiler. To minimize these heat losses, two flue gas heat recovery systems are proposed. The waste heat of flue gas is used for regenerative heating in the heater. This reduces steam extraction from steam turbine and more power is generated. The waste heat recovery of flue gas decreases coal consumption whose utilization is related to environmental issues. This paper presents a thermodynamic analysis of a reference thermal power plant with a rated power of 500 MW to determine the change in power plant output after the proposed systems.

KEYWORDS: Performance, Thermal Power Plant, Waste Exhaust Flue Gas Energy, Heat Loss, Regenerative Heating
\end{abstract}

Received: Nov 24, 2017; Accepted: Dec 14, 2017; Published: Jan 12, 2018; Paper Id.: IJMPERDFEB2018063

\section{INTRODUCTION}

India is one of the countries which are heavily dependent on coal-based energy supply. Coal is easily available and widely distributed in Indian geography but its utilization is related to problems leading to pollution in the atmosphere. According to statistics, the total installed capacity of thermal power plants in India was 213228.9 MW, out of which coal-fired power plants was 187252.88 MW [1]. Therefore, it is highly recommended to decrease the coal consumption.

Heat losses from a power plant are largely due to high-temperature flue gasses leaving into the atmosphere from the boiler. These losses can be reduced by utilizing waste exhaust flue gas energy, resulting in an increase of overall power output and a decrease in coal consumption (which is related to environmental issues). Utilization of flue gas energy depends on the temperature of flue gas dew point [2]. It is known that higher the temperature of flue gas, higher will be the heat losses. Unsuitable heating surface arrangement and variation between The fired coal and the designed coal are some of the factors that may increase the flue gas temperature.

The flue gas heat recovery system is used for utilization of waste exhaust flue gas energy. In this system, the flue gas can be used for the purpose of regenerative heating in the heater which will then reduce the extracted steams from the turbine, resulting in increased turbine output and a net efficiency of the plant. Also, this waste flue gas energy can be used to increase the temperature of inlet air to the boiler for better combustion.

Earlier, different approaches to recovering the waste heat of flue gas have been proposed and developed. One of the approaches is to install a low pressure economizer for waste heat recovery from the exhaust flue gas 
[3]. Davor BIŠCAN and Veljko FILIPAN analyzed the flue gas waste heat potential in Croatian industrial sector [4]. Another approach is to extract a portion of the water vapor and its latent heat from flue gasses based on a nanoporous ceramic membrane capillary condensation separation mechanism [5]. Another approach is optimization of four typical flue gas heat recovery schemes considering thermodynamic, heat transfer and hydrodynamics factors [6].

In this paper, flue gas heat recovery systems with air preheater placed between the boiler \& heater1 and air preheater placed after the heater 1 are proposed. The thermodynamic analysis of both the proposed schemes is investigated and compared.

\section{THERMODYNAMIC ANALYSIS}

\section{Reference Power Plant}

A reference power plant with a rated power of $500 \mathrm{MW}$ is selected and the power output is calculated by determining the value of extracted steams and compared with the proposed schemes. The reference power plant data is listed in table I [12]. According to this data [12], calculations are done and are shown in reference power cycle in figure. 1 and table II.

Table I: Reference Power Plant Data

\begin{tabular}{|c|c|c|c|c|}
\hline Power output (MW) & \multicolumn{4}{|l|}{400} \\
\hline Main steam pressure (bar) & \multicolumn{4}{|l|}{193.47} \\
\hline Main steam temperature $\left({ }^{\circ} \mathrm{C}\right)$ & \multicolumn{4}{|l|}{538.41} \\
\hline Main steam flow (kg/s) & \multicolumn{4}{|l|}{508.05} \\
\hline HRH pressure (bar) & \multicolumn{4}{|l|}{37.84} \\
\hline HRH temperature $\left({ }^{\circ} \mathrm{C}\right)$ & \multicolumn{4}{|l|}{520.65} \\
\hline CRH pressure (bar) & \multicolumn{4}{|l|}{37.84} \\
\hline $\mathrm{CRH}$ temperature $\left({ }^{\circ} \mathrm{C}\right)$ & \multicolumn{4}{|l|}{344.31} \\
\hline Extraction pressure (bar) & 138.71 & 37.73 & 5.08 & 0.30 \\
\hline Condenser pressure (bar) & \multicolumn{4}{|l|}{0.12} \\
\hline Flue gas temperature $\left({ }^{\circ} \mathrm{C}\right)$ & \multicolumn{4}{|l|}{318} \\
\hline Flue gas mass flow rate $(\mathrm{kg} / \mathrm{s})$ & \multicolumn{4}{|l|}{455.83} \\
\hline
\end{tabular}

The reference power plant consists of HP, IP \& LP turbines, three closed type feedwater heaters and a deaerator. The steams are extracted from different stages of turbines (HP, IP and LP) and are used for regenerative heating purposes. Also, this power plant works on reheat cycle, which means the steam leaving the HP turbine passes through a reheater where it is reheated to the superheated temperature at constant pressure. This reheated steam then enters the IP turbine and expands isentropically. Therefore the reference power plant is based on a reheat-regenerative cycle.

\section{Mathematical Model}

The thermodynamic analysis of the reference power plant is carried out by formulating the mass \& energy balance equations, turbine \& pump work equations, total heat supplied from boiler equation and efficiency. Also, the extracted mass flow rates from the turbines (HP, IP and LP) are calculated.

The energy balance equation is:

$m_{a} h_{a}+m_{b} h_{b}=m_{c} h_{c}$

where $m_{a}, m_{b}$ are the mass flow rates entering the heater, $m_{c}$ is the mass flow rate leaving the heater, $h_{a}, h_{b}$ are the 
enthalpies entering the heater and $\mathrm{h}_{\mathrm{c}}$ is the enthalpy leaving the heater.

The mass balance equation is:

$$
\mathrm{m}_{\mathrm{a}}+\mathrm{m}_{\mathrm{b}}=\mathrm{m}_{\mathrm{c}}
$$

where $\mathrm{m}_{\mathrm{a}}, \mathrm{m}_{\mathrm{b}}$ are the mass flow rates entering the heater and $\mathrm{m}_{\mathrm{c}}$ is the mass flow rate leaving the heater.

Turbine work is calculated as:

$$
\mathrm{W}_{\mathrm{T}}=\left(\mathrm{h}_{\mathrm{a}}-\mathrm{h}_{\mathrm{b}}\right)+\left(1-\mathrm{m}_{\mathrm{a}}\right)\left(\mathrm{h}_{\mathrm{b}}-\mathrm{h}_{\mathrm{c}}\right)
$$

where $h_{a}, h_{b}, h_{c}$ are the enthalpies of steam entering or leaving the turbine and $m_{a}$ is the mass flow rate extracted from the turbine.

Pump work is calculated as:

$$
\mathrm{W}_{\mathrm{P}}=v_{\mathrm{bf}}\left(\mathrm{P}_{\mathrm{a}}-\mathrm{P}_{\mathrm{b}}\right)
$$

where $v_{b f}$ is specific volume at $\mathrm{P}_{b}, \mathrm{P}_{\mathrm{a}}$ is boiler pressure and $\mathrm{P}_{\mathrm{b}}$ is condenser pressure.

Heat supplied from boiler is:

$$
\mathrm{Q}_{\mathrm{m}}=\mathrm{m}_{\text {total }}\left(\mathrm{h}_{\mathrm{a}}-\mathrm{h}_{\mathrm{b}}\right)
$$

where $m_{\text {total }}$ is the total mass flow rate, $h_{a}$ is the enthalpy of steam entering the boiler and $h_{b}$ is the enthalpy of feedwater after pump.

Efficiency of power plant is given by:

$$
\eta=\left(\mathrm{W}_{\mathrm{T}}-\mathrm{W}_{\mathrm{P}}\right) / \mathrm{Q}_{\mathrm{m}}
$$

Table II: Calculated Parameters of Reference Power Plant

\begin{tabular}{|l|l|l|l|l|}
\hline \multirow{2}{*}{$\begin{array}{l}\text { Mass flow rate } \\
(\mathrm{kg} / \mathrm{s})\end{array}$} & $\mathrm{m}_{2}$ & $\mathrm{~m}_{5}$ & $\mathrm{~m}_{6}$ & $\mathrm{~m}_{8}$ \\
\cline { 2 - 5 } & 152.61 & 54.27 & 6.78 & 12.53 \\
\hline $\begin{array}{l}\text { Turbine work } \\
(\mathrm{KW})\end{array}$ & $\mathrm{HPT}$ & $\mathrm{IPT}$ & $\mathrm{LPT}$ & Total \\
\cline { 2 - 5 } & 172417.65 & 232627.35 & 120668.25 & 525713.25 \\
\hline $\begin{array}{l}\text { Pump work } \\
(\mathrm{KW})\end{array}$ & $\mathrm{P}_{\mathrm{BF}}$ & $\mathrm{P}_{\mathrm{D}}$ & $\mathrm{P}_{\mathrm{C}}$ & Total \\
\cline { 2 - 5 } & 10460.74 & 6.01 & 140.93 & 10607.68 \\
\hline $\begin{array}{l}\text { Heat supplied } \\
\text { (KW) }\end{array}$ & 1111492.50 & \\
\hline Efficiency \% & 46.343 & \\
\hline
\end{tabular}

\section{Waste Heat Recovery (Method 1)}

In this method, flue gas from boiler enters the air preheater to preheat the air coming from the surrounding atmosphere.

This flue gas then enters the high-pressure feedwater (HP-FW) heater, releasing heat to the higher temperature feedwater. The flue gas is cooled down from $318{ }^{\circ} \mathrm{C}$ to $260.05{ }^{\circ} \mathrm{C}$. This additional flue gas energy apart from the heat supplied by the extracted steam is used for regenerative heating of feedwater in high-pressure heater. This reduces the amount of extracted steam from the turbine, thus increasing both power output and the net efficiency of the plant. 
The extracted steam from the turbine finally returns to the regenerative heating cycle. Assuming a fan draws $10 \mathrm{~m}^{3} / \mathrm{s}$ of air through air preheater, the mass flow rate of air entering the preheater is calculated [7].

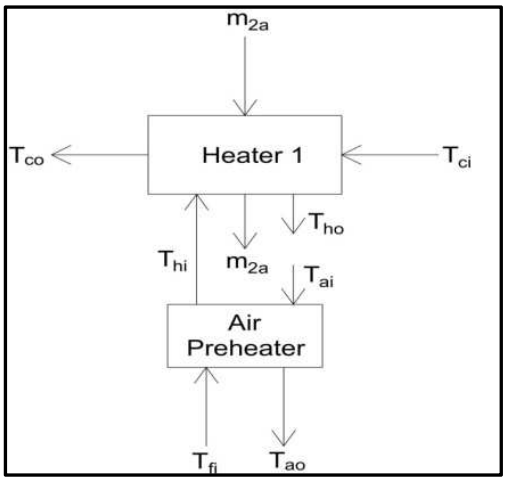

Figure 2: Proposed method 1

\section{Mathematical model}

The thermodynamic analysis of the reference power plant after implementation of proposed method 1 is carried out by formulating the energy balance equation, effectiveness of air preheater equations, changed turbine \& pump work equations, changed heat supplied from boiler equation and increased efficiency. The changed extracted steam from HP turbine and the raised temperature of the combustion air is also calculated.

The effectiveness of heat exchanger is given by:

$$
\varepsilon=\mathrm{Q}_{\text {act }} / \mathrm{Q}_{\max }
$$

The actual amount of heat exchanged is given by:

$$
\begin{aligned}
& \mathrm{Q}_{\text {act }}=\mathrm{m}_{\mathrm{h}} \mathrm{C}_{\mathrm{ph}}\left(\mathrm{T}_{\text {hot inlet }}-\mathrm{T}_{\text {hot exit }}\right) \\
& =\mathrm{m}_{\mathrm{c}} \mathrm{C}_{\mathrm{pc}}\left(\mathrm{T}_{\text {cold exit }}-\mathrm{T}_{\text {cold inlet }}\right)
\end{aligned}
$$

The maximum amount of heat exchanged is given by:

$$
\mathrm{Q}_{\max }=(\mathrm{mC})_{\min }\left(\mathrm{T}_{\text {hot inlet }}-\mathrm{T}_{\text {cold inlet }}\right)
$$

The calculated values of changed mass flow rate, turbine work, pump work, heat supplied from boiler and efficiency are shown in table IV. Also, the temperature of the flue gas entering heater 1, the temperature of the combustion air and the final temperature of flue gas are shown in table III.

Table III: Calculated Temperature in Method 1

\begin{tabular}{|l|l|}
\hline $\mathrm{T}_{\mathrm{hi}}\left({ }^{\circ} \mathrm{C}\right)$ & 312.49 \\
\hline $\mathrm{T}_{\mathrm{ho}}\left({ }^{\circ} \mathrm{C}\right)$ & 260.05 \\
\hline $\mathrm{T}_{\mathrm{ao}}\left({ }^{\circ} \mathrm{C}\right)$ & 258.95 \\
\hline
\end{tabular}


Table IV: Calculated Parameters in Method 1

\begin{tabular}{|l|l|l|l|l|}
\hline $\begin{array}{l}\text { Mass flow rate } \\
(\mathrm{kg} / \mathrm{s})\end{array}$ & $\mathrm{m}_{2 \mathrm{a}}$ & $\mathrm{m}_{5}$ & $\mathrm{~m}_{6}$ & $\mathrm{~m}_{8}$ \\
\cline { 2 - 5 } & 136.29 & 54.27 & 6.78 & 12.53 \\
\hline $\begin{array}{l}\text { Turbine work } \\
(\mathrm{KW})\end{array}$ & $\mathrm{HPT}$ & $\mathrm{IPT}$ & $\mathrm{LPT}$ & Total \\
\cline { 2 - 5 } & 177884.85 & 245275.35 & 127441.05 & 550601.25 \\
\hline $\begin{array}{l}\text { Pump work } \\
(\mathrm{KW})\end{array}$ & $\mathrm{P}_{\mathrm{BF}}$ & $\mathrm{P}_{\mathrm{D}}$ & $\mathrm{P}_{\mathrm{C}}$ & Total \\
\cline { 2 - 5 } & 10460.74 & 6.01 & 149.09 & 10615.84 \\
\hline $\begin{array}{l}\text { Heat supplied } \\
(\mathrm{KW})\end{array}$ & 1121610.90 & \\
\hline Efficiency \% & 48.143 & \multicolumn{4}{|l}{} \\
\hline
\end{tabular}

\section{Waste Heat Recovery (Method 2)}

In this method, the flue gas from boiler directly enters the high pressure feedwater (HP-FW) heater unlike in the case of method 1 in which the flue gas first passes through air preheater and then used for regeneration. This flue gas then enters the air preheater where it heats the air coming from the surrounding atmosphere. The flue gas is cooled down from $318{ }^{\circ} \mathrm{C}$ to $256.65{ }^{\circ} \mathrm{C}$.

Assuming a fan draws $10 \mathrm{~m}^{3} / \mathrm{s}$ of air through air preheater, the mass flow rate of air entering the air heat exchanger is calculated [7].

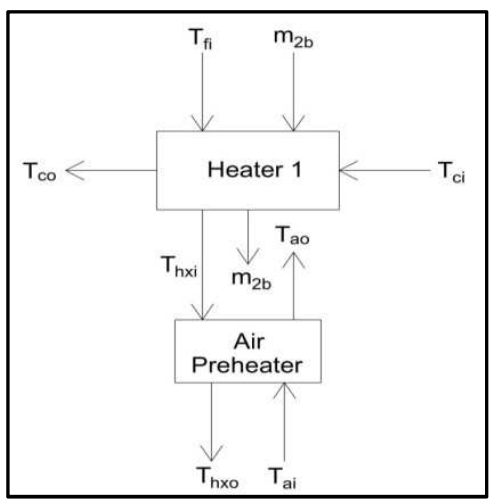

Figure 3: Proposed method 2

The mathematical modeling of the method 2 is similar to that of method 1 .

The calculated values of changed mass flow rate, turbine work, pump work, heat supplied from boiler and efficiency are shown in table VI. Also, the temperature of the flue gas entering air heat exchanger, the temperature of the combustion air and the final temperature of flue gas are shown in table V.

Table V: Calculated Temperature in Method 2

\begin{tabular}{|l|l|}
\hline $\mathrm{T}_{\text {ho }}\left({ }^{\circ} \mathrm{C}\right)$ & 261.16 \\
\hline $\mathrm{T}_{\text {ao }}\left({ }^{\circ} \mathrm{C}\right)$ & 213.48 \\
\hline $\mathrm{T}_{\text {apfo }}\left({ }^{\circ} \mathrm{C}\right)$ & 256.65 \\
\hline
\end{tabular}


Table VI: Calculated Parameters in Method 2

\begin{tabular}{|l|l|l|l|l|}
\hline $\begin{array}{l}\text { Mass flow rate } \\
(\mathrm{kg} / \mathrm{s})\end{array}$ & $\mathrm{m}_{2 \mathrm{~b}}$ & $\mathrm{~m}_{5}$ & $\mathrm{~m}_{6}$ & $\mathrm{~m}_{8}$ \\
\cline { 2 - 5 } & 134.90 & 54.27 & 6.78 & 12.53 \\
\hline $\begin{array}{l}\text { Turbine work } \\
(\mathrm{KW})\end{array}$ & $\mathrm{HPT}$ & $\mathrm{IPT}$ & $\mathrm{LPT}$ & Total \\
\cline { 2 - 5 } & 178350.50 & 246352.60 & 128017.90 & 552721 \\
\hline $\begin{array}{l}\text { Pump work } \\
(\mathrm{KW})\end{array}$ & $\mathrm{P}_{\mathrm{BF}}$ & $\mathrm{P}_{\mathrm{D}}$ & $\mathrm{P}_{\mathrm{C}}$ & Total \\
\cline { 2 - 5 } & 10460.74 & 6.01 & 149.78 & 10616.53 \\
\hline $\begin{array}{l}\text { Heat supplied } \\
(\mathrm{KW})\end{array}$ & 1122472.70 & & \\
\hline Efficiency \% & 48.295 & & \\
\hline
\end{tabular}

\section{RESULTS AND DISCUSSIONS}

Table VII shows the calculation results of the reference power plant and the two proposed methods of waste flue gas energy. In both the methods, output and the efficiency of the power plant are increased. The percentage change in total turbine work between the reference power plant \& the proposed method 1 is $4.73 \%$ and between the reference power plant $\&$ the proposed method 2 is $5.13 \%$. The flue gas waste energy in method 1 is recovered by $57.95^{\circ} \mathrm{C}$ and in method 2 is recovered by $61.35^{\circ} \mathrm{C}$. The proposed method 2 has the best results. It generates extra power of $27 \mathrm{MW}$ and higher plant efficiency of $1.952 \%$. Heat recovered by proposed method 2 saves the extraction of the highest pressure steam by 17.71 $\mathrm{kg} / \mathrm{s}$. Therefore, the results show that proposed method 2 provides higher power output and efficiency.

Table VII: Comparison of Calculated Parameters

\begin{tabular}{|l|l|l|l|}
\hline Parameters & $\begin{array}{l}\text { Reference power } \\
\text { plant }\end{array}$ & Method 1 & Method 2 \\
\hline $\begin{array}{l}\text { Extraction to heater } \\
1(\mathrm{~kg} / \mathrm{s})\end{array}$ & 152.61 & 136.26 & 134.90 \\
\hline $\begin{array}{l}\text { Total turbine work } \\
(\mathrm{KW})\end{array}$ & 525713.25 & 550601.25 & 552721 \\
\hline $\begin{array}{l}\text { Total pump work } \\
(\mathrm{KW})\end{array}$ & 10607.68 & 10615.84 & 10616.53 \\
\hline $\begin{array}{l}\text { Heat supplied from } \\
\text { boiler (KW) }\end{array}$ & 1111492.50 & 1121610.90 & 1122472.70 \\
\hline Efficiency \% & 46.343 & 48.143 & 48.295 \\
\hline
\end{tabular}

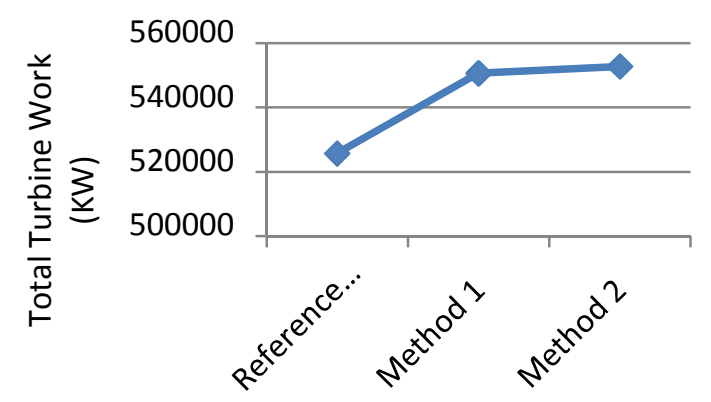

Figure 4: Graph between Total Turbine Work $(\mathrm{KW})$ and Reference Power Plant \& Proposed Methods 


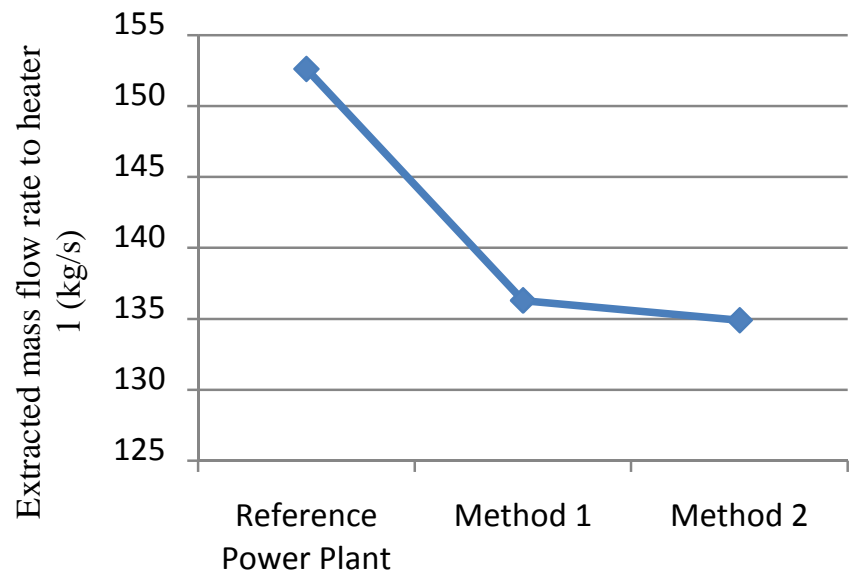

Figure 5: Graph between Extracted Mass Flow Rate to Heater 1 (kg/s)

\section{CONCLUSIONS} and Reference Power Plant \& Proposed Methods

The proposed methods $1 \& 2$ obtain higher power output and plant efficiency. Compared to the values obtained in the reference power plant, both the proposed methods show increase in total turbine output. The conclusions drawn from this work are:

- the recovery of flue gas waste heat reduces flue gas temperature and lead to an increase in power plant efficiency $\&$ also reduces the harmful effects of global warming,

- the flue gas waste energy is recovered by nearly $58^{\circ} \mathrm{C}$ in all the proposed methods, and

- the increase in efficiency is $1.80 \%$ and $1.952 \%$ for proposed methods 1 and 2 respectively.

\section{NOMENCLATURE}

Q - $\quad$ amount of heat exchange, $[\mathrm{KW}]$

$\mathrm{m}$ - $\quad$ mass flow rate, $[\mathrm{kg} / \mathrm{s}]$

$\mathrm{C}_{\mathrm{p}}-\quad$ specific heat at constant pressure, $\left[\mathrm{kJkg}^{-1 \circ} \mathrm{C}^{-1}\right]$

$\varepsilon-\quad$ effectiveness

$\mathrm{T}$ - $\quad$ temperature, $\left[{ }^{\circ} \mathrm{C}\right]$

P - $\quad$ pump work, $[\mathrm{KW}]$

\section{Subscripts}
act - actual
max - maximum
2 - $\quad$ extraction to heater 1
5 - $\quad$ extraction to heater 2
6 - extraction to deaerator 


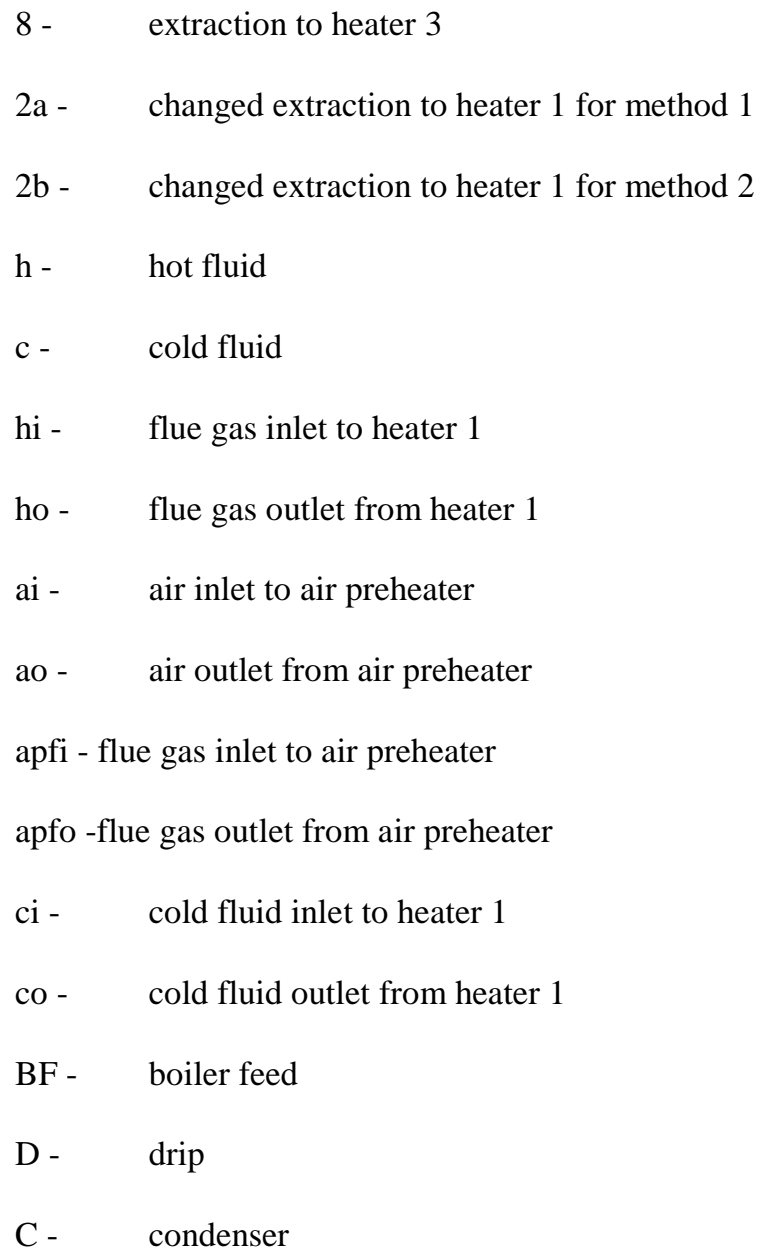

\section{Acronyms}

HPT - high pressure turbine

IPT - intermediate pressure turbine

LPT - low pressure turbine

H1 - heater 1

H2 - heater 2

DEA - deaerator

H3 - heater 3

\section{REFERENCES}

1. Government of India, Ministry of Power Central Electricity Authority New Delhi, Power Sector September 2016

2. Petr Stehlik, Conventional versus Specific Types of Heat Exchangers in the Case of Polluted Flue Gas as the Process fluid - A Review, Applied Thermal Engineering, 31 (2011), 1, pp. 1-13

3. Chaojun Wang, Boshu He, Shaoyang Sun, Ying Wu, Na Yan, Linbo Yan, Xiaohui Pei, Application of a low pressure economizer for waste heat recovery from the exhaust flue gas in a $600 \mathrm{MW}$ power plant, Energy, 48 (2012), 1, pp. 196-202 
4. Davor BIŠCAN and Veljko FILIPAN, Potential of Waste Heat in Croatian Industrial sector, Thermal Science, 16 (2012), 3 , pp. $747-758$

5. Dexin Wang, Ainan Bao, Walter Kunc, William Liss, Coal power plant flue gas waste heat and water recovery, Applied Energy, 91(2012), 1, pp. 341-348

6. Gang Xu, Shengwei Huang, Yongping Yang, Ying Wu, Kai Zhang, Cheng Xu, Techno-economic analysis and optimization of heat recovery of ytility boiler flue gas, Applied Energy, 112 (2013), pp. 907-917

7. PK Nag (2011), Power Plant Engineering, Tata McGraw Hill Education Private Limited, Third edition

8. PK Nag (2011), Engineering Thermodynamics, Tata McGraw Hill Education Private Limited, Fourth edition

9. C P Kothandaraman and S Subramanyan (2015), Heat and Mass Transfer Data Book, New Age International Publishers, Eight edition

10. S.M. Yahya (2014), Gas Tables for Compressible Flow Calculations, New Age International Publishers, Sixth edition

11. K.K Ramalingam, Steam Tables SI Units, Scitech Publications (INDIA) Pvt. Ltd.

12. Verbal Communication with Relevant Technical Staff of the Plant

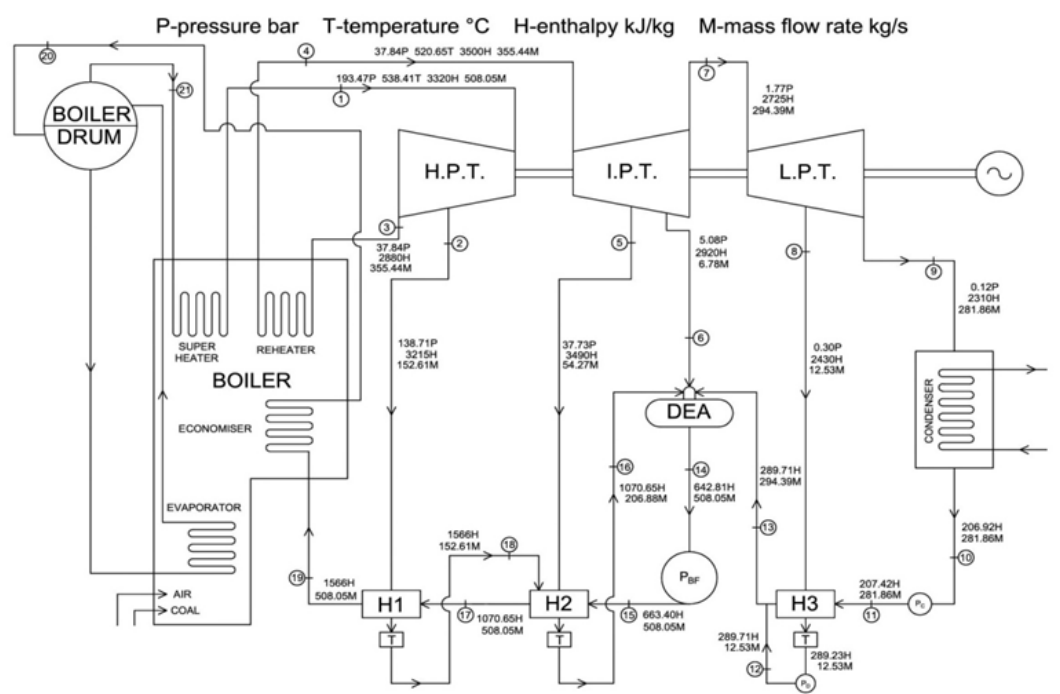

Figure 1: Reference Power Plant Cycle 
